【カテゴリー II 】

日本建築学会構造系論文集 第82巻 第737号, 1047-1054, 2017年7月 J. Struct. Constr. Eng., AIJ, Vol. 82 No. 737, 1047-1054, Jul., 2017 DOI http://doi.org/10.3130/aijs.82.1047

\title{
2016 年熊本地震での杭基礎の被害とその要因に関する解析
}

\author{
ANALYSES OF DAMAGE TO PILE FOUNDATIONS BY \\ THE 2016 KUMAMOTO EARTHQUAKE
}

\author{
金子 治*, 成田修英** \\ Osamu KANEKO and Nobuhide NARITA
}

\begin{abstract}
The authors investigated the damage of pile foundations during the 2016 Kumamoto earthquake and carried out simulation analyses to estimate a cause of the damage. A static analysis model consisted of both piles and ground springs considering nonlinearity was employed, and the lateral load at pile top calculated based on observed earthquake motion and ground displacement were given. Obtained bending moment or shear force by analyses almost accords with the actual damage situation when ground displacement by the cause except the earthquake motion was added.
\end{abstract}

Keywords : Pile Foundations, The 2016 Kumamoto earthquake, Earthquake damage, Differential movement of soils, Response displacement method, Soil reaction spring 杭基礎，地震被害，2016 年熊本地震，地盤変位，応答変位法，地盤ばね

\section{1. はじめに}

2016 年熊本地震では木造建築物の被害や地盤災害が多く報告さ れているが，鉄筋コンクリート造や鉄骨造の建築物の被害は主に 1981 年の耐震基準の改正以前のもので, 戸建住宅以外で基礎構造の 被害が推定される建物の報告は少ない 1)。一方, 2011 年東北地方太 平洋沖地震では杭基礎の被害が東北地方から関東地方まで広い範囲 で見られており, 液状化地盤以外や震度 5 強程度の地震動の場所で の被害事例もある ${ }^{2)}$ このことから, 本地震においても杭基礎の被 害は潜在している可能性があると考えられ, 今後調查が進めば被害 の報告が増えることが予想される。

本論文では, 震度 7 が観測された震源に近い地区において杭の調 查が行われた建物（以下, 「本建物」という）について, 被害状況を 報告するとともに杭の被害の発生要因に関する検討を行った。本建 物では杭に対する耐震設計が実施されているが, 2011 年東北地方太 平洋沖地震での杭の被害発生要因の検討事例では, 耐震性確保のた めには杭ごとに負担軸力を考慮して杭体・杭頭接合部の荷重-変形関 係の評価や地震動の継続時間に応じた繰返し載荷の影響など大地震 時に顕著となる要因や群杭効果を含む地盤の非線形性や地盤変形の 影響など地盤に関わる影響要因をより詳細に考慮すべきことが指摘 されている31,4)。そこで, 本建物に対しても文献 3)・4)で示された影 響要因に加え, 断層からの距離などの特有の条件も考慮したシミュ
レーション解析を実施し, 解析手法の適用性を確認寸るとともに被 害発生要因の分析を行った。さらにこれらの解析結果から, 既往の 耐震設計に準じた解析結果との比較と合わせ, 大地震時の杭の構造 性能評価における地盤変位の考慮の必要性について検討した。

\section{2. 被害建物の概要および杭の被害状況}

本建物は熊本県益城町西部の沖積低地上に既存建物にエクスパン ションジョイントを介して増設される形で 2009 年に建設された施 設で, 南側は河川堤防に隣接している。建物規模は $\mathrm{RC}$ 造地上 2 階 地下なし・建物高さ $14.45 \mathrm{~m} \cdot 2 \times 1$ スパンの耐力壁付きラーメン構 造で, Fig.1 に濃い色で示した南面 1 階西側スパンのみが耐力壁で ある。既存建物は北側にあり地下 1 階地上 3 階・ $3 \times 3$ スパンである。 Fig. 2 に杭伏図を示寸が, 杭種は杭径 $600 \mathrm{~mm}$ の遠心力高強度プレ ストレストコンクリート杭（PHC 杭）で，上杭 C 種 $12 \mathrm{~m}$ （埋込み 部を含む）＋下杭 A 種 $15 \mathrm{~m}$, 施工方法はプレボーリング拡大根固め 工法で長期許容支持力は $1100 \mathrm{kN} /$ 本， 1 柱に $2 \sim 3$ 本・計 14 本配置 されている。以下, 杭番号は Fig.2 に示した No.を用いる。杭頭レ ベルは GL-2.0m（TP+6.5m）で，杭頭は杭径の 1 倍（600mm）が パイルキャップ内に埋め込まれ，杭頭接合筋（補強筋）はなく, 中 詰めコンクリート $\left(F_{c}=21 \mathrm{~N} / \mathrm{mm}^{2}\right)$ はパイルキャップ下端まで打設 されている。同時に建設された施設の構造計算書ではレベル 2 地震
* 戸田建設(株)技術開発センター 博士 (工学)

** 戸田建設(株)技術開発センター 修士(工学) 
時の設計水平震度 $k=0.6$ に対する杭の終局耐力の検討がされており， 同じ耐震設計と考えられる。

地盤は Fig. 3 に示寸柱状図のように, $3 \sim 4 \mathrm{~m}$ 程度の盛土の下は $N$ 值 1 7 の腐植土を挟む沖積粘性土層で, GL-14m（TP-5.2m）から 砂碩と粘性土の互層が，GL-27m（TP-18.2m）以深に支持層とな る $N$ 值 60 以上の層が出現する。地下水位は GL-1.75m(TP+7.05m) である。 $N$ 值以外の地盤情報は得られていない。

これらの建物条件を 2011 年東北地方太平洋沖地震において杭の 被害のあった建物 2) と比較すると, 沖積低地に建設されている・中 低層建物・既製コンクリート杭など，共通する事項が多い。

地震後には本建物と既存建物間のエクスパンションジョイントの 破損が見られ，Fig.2 に示すように既存建物に対し最大 $166 \mathrm{~mm} の$ 相対沈下と EW 方向 1/73(109/8000) - NS 方向 1/455 (11/5000)の傾 斜の発生，および杭頭部の破損が確認された。被災度区分 5) は「大 破」と判定される。これにより本建物は稼働停止したが, 施設全体 の操業は別系統で継続されており, 上部構造には非耐力壁を含め外

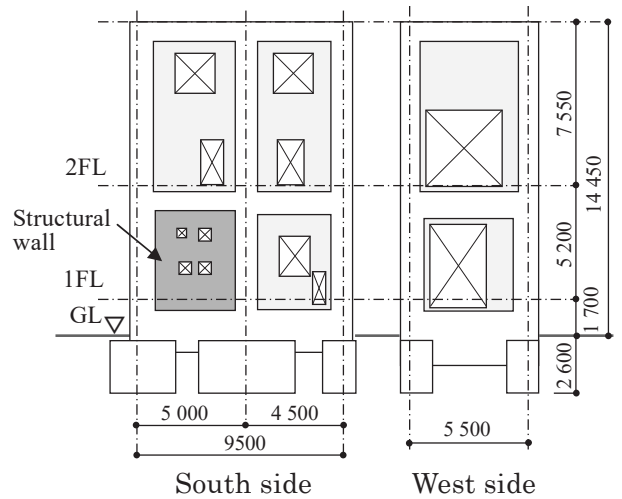

Fig. 1 Elevation of the building

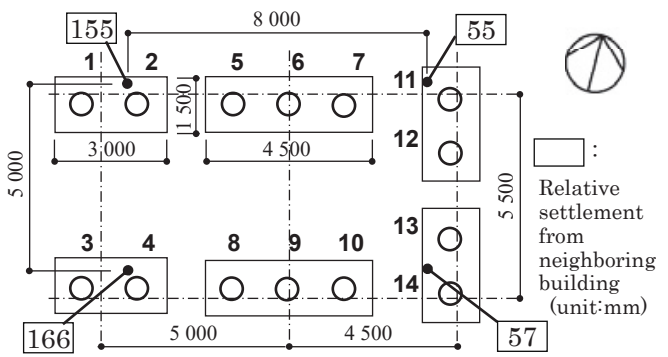

Fig.2 Pile plan and observed settlement

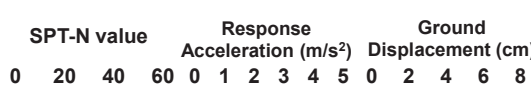
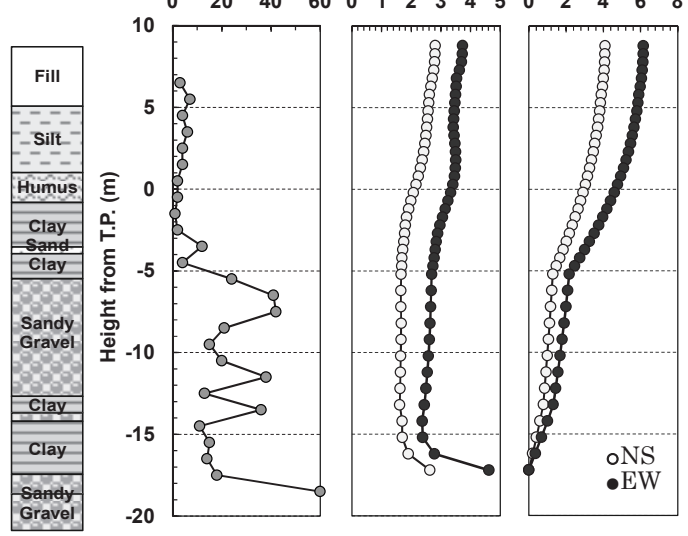

Fig. 3 Soil profile log and response value

観上の被害が全く認められないことから, 基礎構造の補修および建 物のジャッキアップを行って再使用されることとなった。なお，地 震後に敷地全体で 200 300 $\mathrm{mm}$ 程度の地盤の沈下が生じたが，噴砂 は見られなかった。また, 既存建物との水平方向のずれや建物周囲 の地割れ等は見られず建物の水平移動は生じていないと判断される。 補修工事あたって杭頭から $1.8 \mathrm{~m} （ \mathrm{TP}+4.1 \mathrm{~m}$ ) まで掘削して確認 された各杭の被害状況について, 南側から見たスケッチを Fig.4に, 代表例の写真を Photo1 に示す。すべての杭が建築基礎の被災度区 分判定 5)に示された損傷度 Vに相当するが，状況は同じパイルキャ ップの杭であってもそれぞれ異なっている。パイルキャップの損傷 や杭頭の抜け出しは認められなかった。これらを大別すると破壊パ ターンは以下のようになる。

(1)杭頭部せん断破壊（No.1,No.8,No.13,No.4は(1)(2)の中間)

せん断破壊の方向は， $\mathrm{E} \rightarrow \mathrm{W}$ 方向である。

(2)杭頭部曲げ圧壊（No.3,No.5,No.6,No.7,No.9,No.10,No.11,No.12）

No.3，No.5 では縦ひび割れが，No.5，No.6，No.9の杭頭では $\mathrm{PC}$ 鋼材の破断が見られた。

(3)杭頭よりやや深い位置でのせん断破壊(No.14)

せん断破壊の方向は，W $\rightarrow \mathrm{E}$ 方向である。

(4)杭頭部破断+傾斜(No.2)

杭の傾斜量は 4.4/100, 杭頭でのずれ幅約 $100 \mathrm{~mm}$ で, 杭頭から $2.3 \mathrm{~m}$ 付近の深さで折れ曲がりが生じている可能性がある。

さらに, 衝撃弾性波を用いた非破壊試験結果を Table1 に示寸（継 手と思われる試験結果は除いた）が，すべての杭で杭頭から $3 \sim 6 \mathrm{~m}$ 付近の地中部でひび割れ等の破損の可能性があると推定された。
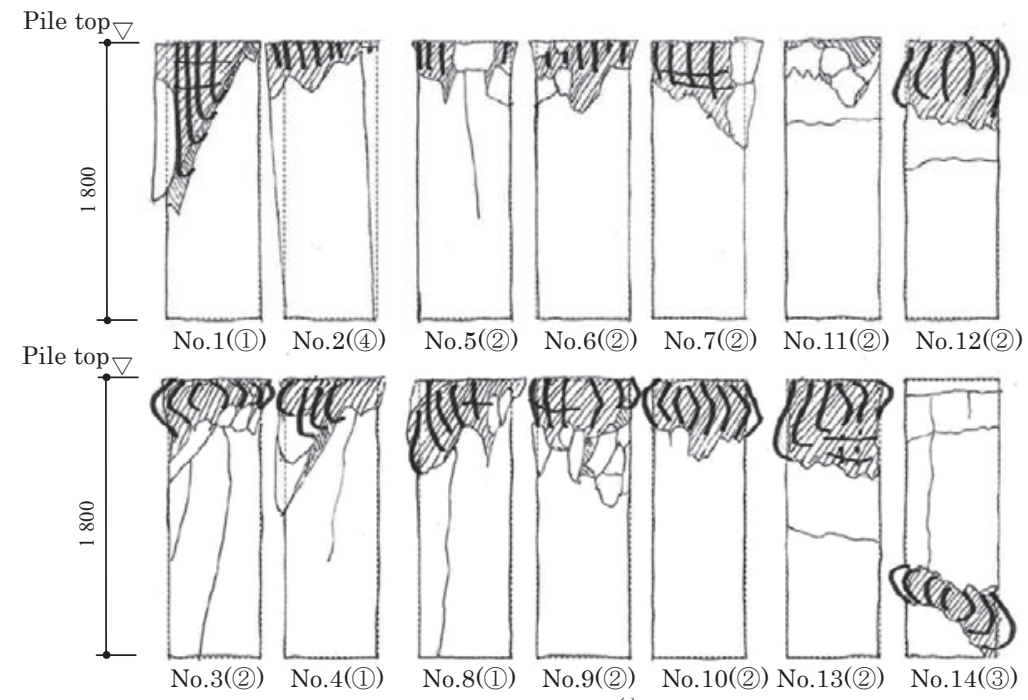

( ): Classification of damage pattern

Fig.4 Schematic view of damage to piles from south side
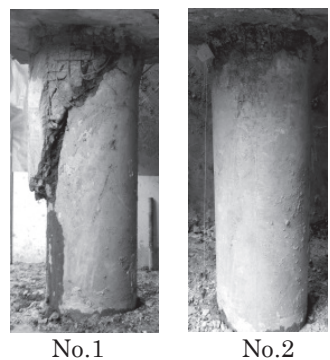

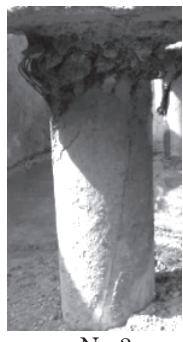

No.3

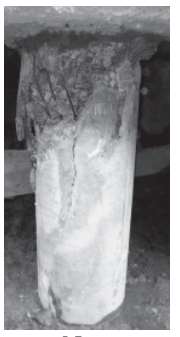

No.8

Photo1 Typical damage to piles

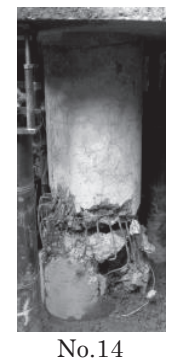

No. 14 
Table1 Depth from pile top at estimated damages

\begin{tabular}{l|cccccccccccccc}
\hline Pile No. & 1 & 2 & 3 & 4 & 5 & 6 & 7 & 8 & 9 & 10 & 11 & 12 & 13 & 14 \\
\hline Depth & 3.5 & 3.4 & 4.7 & 4.5 & 3.2 & 2.4 & 2.8 & 3.2 & 4.2 & 3.2 & 2.6 & 2.8 & 3.7 & 4.9 \\
from & 3.9 & 4.2 & 5.2 & 4.9 & 3.9 & 3.9 & 3.5 & 3.9 & 5.1 & 4.4 & 4.0 & 3.6 & 4.3 & 5.5 \\
pile top & 5.2 & 5.8 & 5.6 & 6.0 & 5.2 & 4.7 & 4.6 & 4.6 & 6.2 & 5.4 & & 4.3 & 5.4 & 5.9 \\
& & & 6.7 & & 6.6 & & & & 6.9 & & & & & \\
(unit:m) & & & & & & & & & 8.5 & & & & & \\
\hline
\end{tabular}

\section{3. 解析モデル}

被害要因検討のための解析では, 剛な梁で繋いだ杭 14 本および地

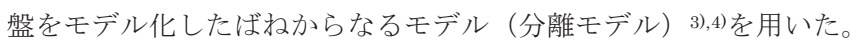

与える荷重・外力は杭頭水平力および地盤変位であり, 約 $3 \mathrm{~km}$ 離 れた防災科学技術研究所基盤強震観測網(KIK-net) 益城観測点 (KMMH16) における 2016 年 4 月 16 日の本震記録を用いて求めた。 観測点は台地上で本敷地は低地にあり標高は異なるものの地層構成 は類似していることから，観測点の地表記録（TP+55m・EW 方向 最大加速度 $\left.11.56 \mathrm{~m} / \mathrm{s}^{2}\right)$ を粘性土の下に出現する砂層・砂碩層 $(\mathrm{TP}+$ $14 \mathrm{~m}$ 以深）に戻した地震動を本敷地の砂砂層（TP-5.2m 以深）で も同一と考え, これを入力地震動として地震応答解析を行った。せ 几断波速度 $V_{s}$ は太田らの提案式 ${ }^{6)}($ 式(1) ) を, 非線形性 $(G-\gamma$ 関係. $h-\gamma$ 関係) は平均粒径と拘束圧に基づく安田らの提案式 7)を用いて設 定した。得られた最大加速度分布および地盤変位を Fig.3 に示す。

$$
V_{s}^{\prime}=68.79 N^{0.171} H^{0.199} Y_{g} S_{t}
$$

ここで， $V_{s}^{\prime}$ : 換算せん断波速度, $N: N$ 值， $H$ : 地表面からの高さ， $Y_{g}$ : 地 質年代係数（沖積層 1.000 , 洪積層 1.303）, St : 土質に応じた係数（粘土 1.000 ，細砂 1.086，中砂 1.066，粗砂 1.135，砂磎 1.153，磞 1.448）

以下の解析では観測波の振幅の大きさおよび杭の被害状況を考慮 し $\mathrm{E} \rightarrow \mathrm{W}$ 方向の解析について示寸。ここで, 杭の被害は本震のみに より生じたと仮定し, かつ 2011 年東北地方太平洋沖地震に比べ主 要動の継続時間は短いことから, 連鎖的な破壊の進行 4) は考慮せず, 載荷は 1 方向のみとした。

杭頭水平力および軸力は, 上部構造の被害はほぼ見られなかった ことから弾性応答の範囲内にあったとして, 根入れを考慮した有効 入力を 0.9 倍として地表面最大応答加速度 $\alpha_{\max }\left(3.73 \mathrm{~m} / \mathrm{s}^{2}\right) / g \times 0.9=$ 0.336 を基礎階（1 階床）の層せん断力係数とし, 基礎階を含む層 せん断力分布を $A_{i}$ 分布として算定した。計算は建築構造計算用一連 プログラム(Super Build/SS3)用いて, 得られた基礎階のせん断力か ら慣性力最大時の杭頭水平力を, 各柱脚の支点反力から杭の軸力の 最大值を求めた。Fig.5 に基礎固定条件で求めた上部構造の $\mathrm{E} \rightarrow \mathrm{W}$ 方向載荷時の層せん断力 $Q$-層間変形角 $R$ 関係を示寸が, 2 階床の 層せん断係数 $C_{B}=0.43$ は上部構造にほぼ被害の生じないレベルで あり，実際の状況と対応している。

本解析では軸力ごとにグループ化して被害傾向を評価するため, 各杭の軸力を Table2 のように設定し, 杭の荷重-変形関係の非線形 性を考慮した。解析では鉛直方向に地盤ばねは設けず軸力は全長一

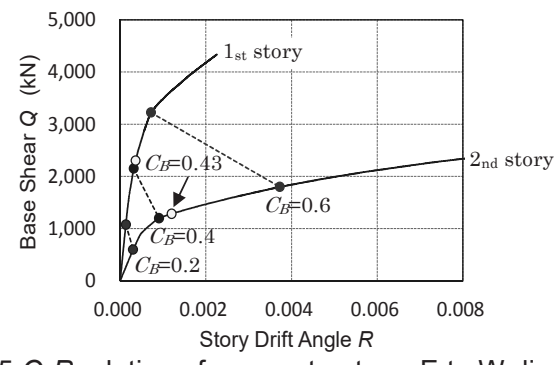

Fig.5 $Q-R$ relation of upper structure: $\mathrm{E}$ to $\mathrm{W}$ direction
Table2 Arrangement of axial load

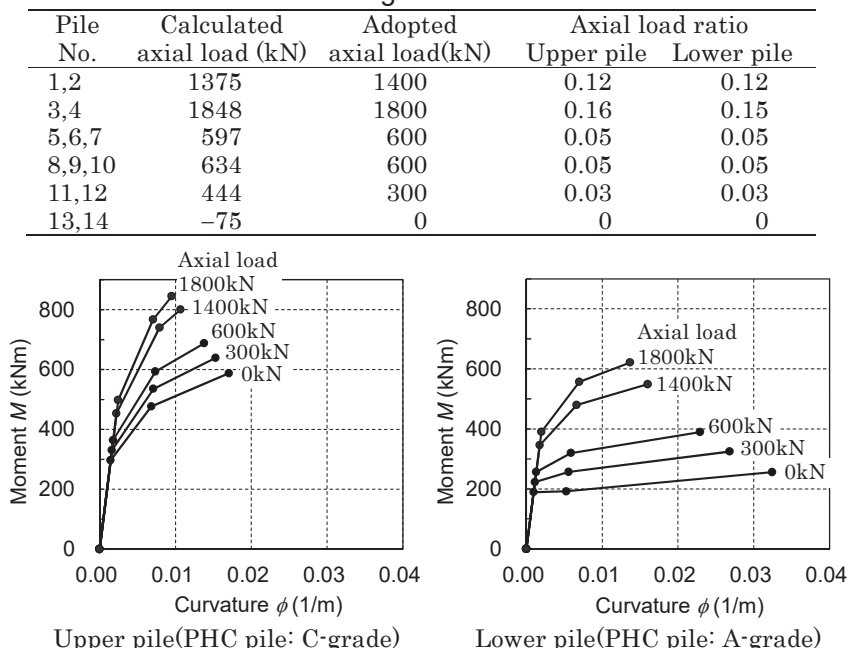

Fig.6 $M-\phi$ relation of piles

定かつ全ステップ最大值で一定として, 杭種ごとの断面解析により ひび割れ曲げモーメント $M_{c}$ ，降伏曲げモーメント $M_{y}$, 終局曲げモ 一メント $M_{u}$ とその時の曲率 $\phi$ を求め, Fig.6 に示すようなトリ・リ ニア型にモデル化した。材料特性は公称值（設計值）を用いて，コ ンクリートは設計基準強度 $85 \mathrm{~N} / \mathrm{mm}^{2}$ ・ヤング率 $40000 \mathrm{~N} / \mathrm{mm}^{2}$ ・終 局ひずみ $0.25 \%$ (圧縮) とするバイ・リニアモデル， PC 鋼材は降 伏強度 $1275 \mathrm{~N} / \mathrm{mm}^{2}$ ・破壊強度 $1420 \mathrm{~N} / \mathrm{mm}^{2}$ ・終局ひずみ $1.5 \%$ （引 張）とするトリ・リニアモデルとした。せん断変形やせん断耐力の 上限值は考慮していない。杭頭部は，埋込み長をほぼ剛接と見なせ る杭径の 1 倍 ${ }^{8)}$ とており, かつ地震後の抜出しも認められないこ とから固定条件とした。

地盤ばねは，双曲線モデルに基づく間瀬・中井の提案 9)を用いて 求めた地盤反力 $p$-水平変位 $y$ 関係を多折れ線にモデル化した。用い た各層の地盤定数を Table 3 に示すが，せん断波速度 $V_{s}$, 粘着力 $c$, 内 部摩擦角 を示寸定数 $u$ (小さいほど緩やかに近づく9）は $N$ 值と上載圧を考 慮して設定した。初期剛性 $K_{0}$ および塑性地盤反力 $p_{y}$ については前 方杭（載荷方向外端の杭）および後方杭（内部の杭）に分けて本会 「建築基礎構造設計指針」10)に示された係数 $\xi, \kappa, \lambda, \mu$ を用いて群杭効果 を評価した。杭間隔 $R$ は $\mathrm{EW}$ 方向の平均值 $(1.72 \mathrm{~m})$ とした。設定し た係数を Table4 に示寸が, 前方杭については参考文献 10)に「加力 最前列に位置する杭において, 杭頭部の分担荷重や曲げモーメント が大きくなる」とあることを考虑して, 水平地盤反力に対する係数 $\xi$ を 1.0 とした。Fig.7 に解析に用いた地盤ばねの $p-y$ 関係を示す。 図中には前方杭/粘性土層/No.2 $\cdot$ No.8 層について, 参考文献 10)に基

Table3 Property of soil layer

\begin{tabular}{rrrrccrrrr}
\hline No. $\begin{array}{c}\text { Lowest } \\
\text { level } \\
(\mathrm{TP}-\mathrm{m})\end{array}$ & $\begin{array}{c}\text { Soil } \\
\text { Classification }\end{array}$ & $\begin{array}{c}\text { SPT- } \\
N^{N} \text { value }\end{array}$ & $\begin{array}{c}V_{s}^{*} \\
(\mathrm{~m} / \mathrm{s})\end{array}$ & $\begin{array}{c}c^{*} \\
\left(\mathrm{kN} / \mathrm{m}^{2}\right)\end{array}$ & $\phi^{*}$ & $\begin{array}{c}K_{0} \\
\left(\mathrm{MN} / \mathrm{m}^{2}\right)\end{array}$ & $\begin{array}{c}P_{y} \\
(\mathrm{kN} / \mathrm{m})\end{array}$ & $u$ \\
\hline 1 & 5.2 & Fill & 5 & 137 & 31.3 & 0.0 & 102 & 169 & 20 \\
2 & 1.2 & Silt & 6 & 182 & 37.5 & 0.0 & 188 & 203 & 20 \\
3 & -0.6 & Humus & 2 & 126 & 20.0 & 0.0 & 79 & 162 & 50 \\
4 & -3.3 & Clay & 1.5 & 114 & 20.0 & 0.0 & 69 & 162 & 50 \\
5 & -3.7 & Sand & 12 & 183 & 0.0 & 35.4 & 194 & 2134 & 50 \\
6 & -5.2 & Clay & 4 & 159 & 25.0 & 0.0 & 140 & 162 & 75 \\
7 & -12.3 & Sandy Gravel & 28.7 & 245 & 0.0 & 40.0 & 386 & 4715 & 75 \\
8 & -13.3 & Clay & 13 & 235 & 81.3 & 0.0 & 329 & 439 & 100 \\
9 & -13.8 & Sandy Gravel & 36 & 264 & 0.0 & 40.0 & 454 & 5503 & 100 \\
10 & -17.0 & Clay & 14.5 & 244 & 90.6 & 0.0 & 356 & 489 & 100 \\
11 & -20.5 & Sandy Gravel & 60 & 313 & 0.0 & 40.0 & 694 & 6397 & 100 \\
\hline \multicolumn{7}{c}{} & \multicolumn{7}{c}{ *Converted using SPT N-value } & &
\end{tabular}


Table4 Coefficient for pile group effect

\begin{tabular}{lcccccc}
\hline Pile No. & Position & $R / B$ & $\xi$ & $\kappa$ & $\mu$ & $\lambda$ \\
\hline 1,3 & Front & - & 1.0 & 3.0 & 1.40 & 9.0 \\
$2,4 \sim 14$ & Back & 2.87 & 0.53 & 0.96 & 1.32 & 8.6 \\
\hline
\end{tabular}
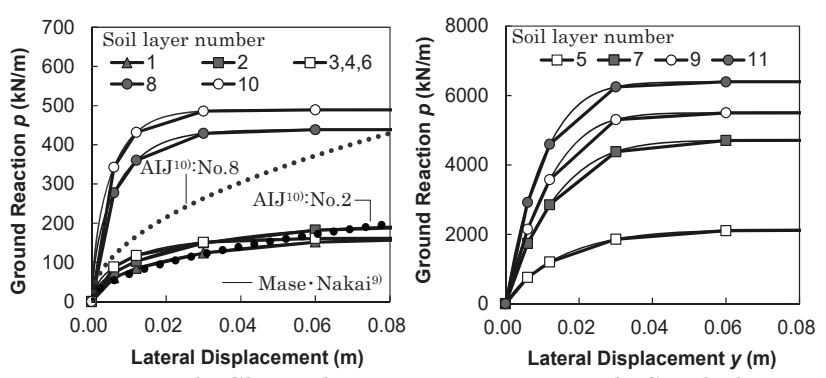

Front side/Clayey layer

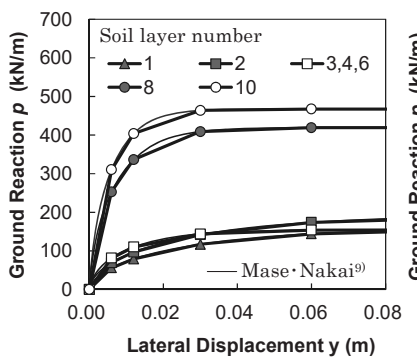

Back side/Clayey layer

Fig.7 $p-y$ relation of soil springs

づく $p-y$ 関係（「AIJ」）も点線で示すが，被害が生じた表層 $(u=20)$ では概ね対応し，地中部 $(u=100)$ は剛性を高く評価している。

解析モデルにおける杭の節点 (分割) 間隔は, 上杭は杭径の $1 / 2$ の $300 \mathrm{~mm}$ ・下杭は杭径と同じ $600 \mathrm{~mm}$ とし, 杭頭水平力および地 盤変位を同時・同方向に最大值まで等間隔 30 ステップの増分で与 えた。地盤変位は杭先端からの相対值を地盤ばねを介して与えた。

\section{4. 解析ケース}

被害要因検討のため, 3 節の方法で求めた杭頭水平力および地盤 変位を荷重・外力としたケース（Case1）を基本として，仮定条件 が含む誤差や地盤のばらつき等を考えて杭頭水平力もしくは地盤変 位を 1.5 倍としたケース（Case2-1,Case2-2）を実施した。

さらに, 本敷地は断層変位が報告されている布田川断層帯および 日奈久断層帯の延長線が交差する位置近くにあり，液状化や側方流 動はなかったと考えられるが, 地震後に地盤沈下や地割れの発生や 盛土擁壁の一部に破損も見られた。そこで，杭被害の説明のための 仮定として, 地盤震動以外の水平地盤変位が盛土層および表層で最 も軟弱な腐植土層に発生したと想定した。この変位は同時発生も考 えられるが,それぞれの影響を分けて評価するため別ケースとした。

想定する変位を腐植土層の下端境界部（TP-0.6m/杭頭 $-7.1 \mathrm{~m} ）$ に おいて $50 \mathrm{~mm}$ または $10 \mathrm{~cm}$ とした場合をCase3-1A·Case3-1B, 盛 土層の下端境界部（TP+5.2m/杭頭 $-1.3 \mathrm{~m} ）$ において, 表層に近いこ とから建物の上載圧や杭による拘束効果も考慮し外端の No.1,No.3 を $60 \mathrm{~mm}$ ・中央部を $50 \mathrm{~mm}$ ・奥に位置する No.11 14 40mm とし た場合を Case3-2 とし, 地震動と同方向に加えた。変位量は地盤の 状況等を考慮した工学的判断によるもので, 定量的評価は今後の課 題である。各ケースの解析条件を Table 5 に, 設定した地盤変位を Fig.8 に示す。さらに原設計と同様の, 設計水平震度 $k=0.6$-地盤変 位なし，としたケース（Case4）も実施して比較検討を行った。
Table5 Analysis case(Load condition)

\begin{tabular}{cll}
\hline Case & Lateral load at pile head: $P$ & Distribution of Ground displacement \\
\hline 1 & $P=254 \mathrm{kN}\left(C_{B}=0.43\right)$ & Response value $\left(d_{\max }=60.1 \mathrm{~mm}\right)$ \\
\hdashline $2-1$ & $P=381 \mathrm{kN}\left(C_{B}=0.43 \times 1.5\right)$ & Response value $\left(d_{\max }=60.1 \mathrm{~mm}\right)$ \\
\hdashline $2-2$ & $P=254 \mathrm{kN}\left(C_{B}=0.43\right)$ & Response value $\times 1.5\left(d_{\max }=90.2 \mathrm{~mm}\right)$ \\
\hdashline $3-1 \mathrm{~A}$ & $P=254 \mathrm{kN}\left(C_{B}=0.43\right)$ & $\begin{array}{l}\text { Added } 50 \mathrm{~mm} \text { to response value } \\
\text { at the bottom of humus layer }\end{array}$ \\
\hdashline $3-1 \mathrm{~B}$ & $P=254 \mathrm{kN}\left(C_{B}=0.43\right)$ & $\begin{array}{l}\text { Added } 100 \mathrm{~mm} \text { to response value } \\
\text { at the bottom of humus layer }\end{array}$ \\
\hdashline $3-2$ & $P=254 \mathrm{kN}\left(C_{B}=0.43\right)$ & $\begin{array}{l}\text { Added } 40 \sim 60 \mathrm{~mm} \text { to response value } \\
\text { at the bottom of fill }\end{array}$ \\
\hline 4 & $P=454 \mathrm{kN}(k=0.6)$ & None \\
\hline
\end{tabular}
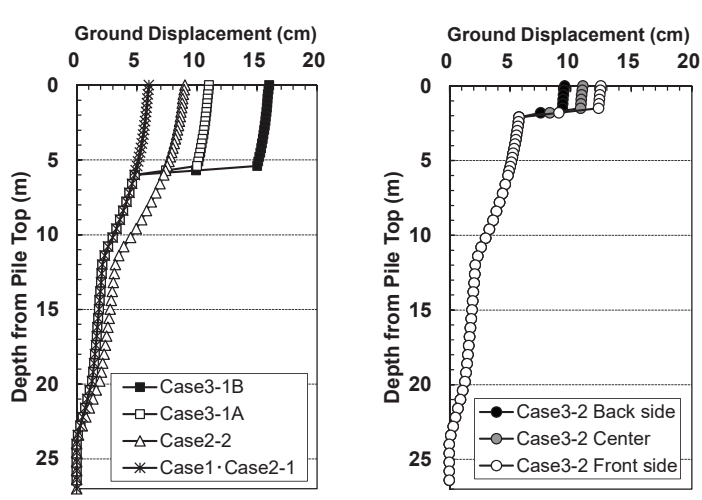

Fig.8 Assumed distribution of ground displacement

\section{5. 解析結果}

Case1 の解析結果について, 軸力が最大・最少となる南側の No.3. No.4・No.8/9/10・No.13/14 および北側の No.1・No.11 の曲げモーメ ント分布およびせん断力分布を Fig.9 に示す。曲げモーメント図に は断面解析によって求めた降伏曲げモーメント $M_{y}$ および終局曲げ モーメント $M_{u}$ を，せん断力図には岸田らの提案 ${ }^{11} に$ 基づく設計式 により計算した設計せん断耐力 $Q_{u}$ を示した。ここで, シアスパン 比 MIQd は曲げモーメント図に示すように杭頭位置でも 3 以上であ ることから $M / Q d=3$ とした。中詰めコンクリートは考慮していない。 また, 設計式では危険率 $5 \%$ として提案式に 0.8 を乗じているが, これを考慮しない值も破線で示した。

ここで, すべての杭で曲げモーメントは降伏曲げモーメントに達 せず，せん断力もせん断耐力以下であり，3 節で示した方法により 設定した荷重・外力では杭は損傷に至らない結果となった。また, 本敷地の上杭部分は群杭効果 (Table 4 の $\mu, \lambda$ ) の小さい粘性土地盤 が大部分を占めており, 前方杭 No.3 と後方杭 No.4の上杭部分の発 生応力は差はごくわずかであり，地盤反力に対する群杭効果は破壊 の発生にはほとんど影響を与えなかったと考えられる。

さらに Fig.10·Fig.11 に, 荷重・外力の設定精度を考慮して杭頭 水平力 $($ Case2-1） あるいは地盤変位（Case2-2）を 1.5 倍したケー スについて, 軸力最大の No.3 と最小の No.13/14 および No.8/9/10 の曲げモーメント分布を示すが，いずれも実際の破壊状況に比べて 発生応力は小さい。杭頭水平力 1.5 倍は層せん断力係数 0.64 に相当 $し$, Fig.5 の $Q-R$ 関係と実際の状況を比較すると上部構造への入力 としては過大であるが，それでも杭は損傷に至っていない。また， 地盤変位を成層地盤の地震応答解析で求められる值を 1.5 倍しても 損傷には達せず, 応力分布も杭頭以外の被害の発生とは対応しない。 これらの結果から，杭頭水平力および地盤震動による変位のみでは 被害の説明は難しいことがわかる。 

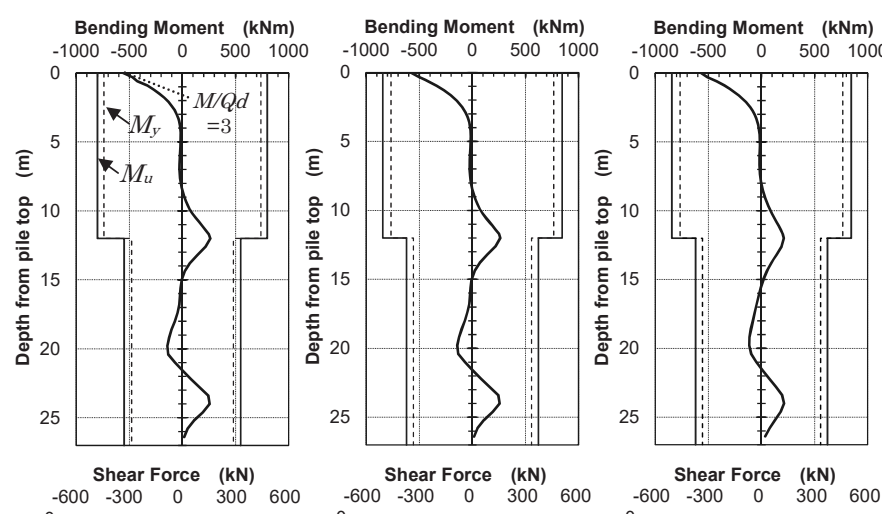

Bending Moment $\quad(\mathbf{k N m})$
$-1000-500 \quad 0 \quad 500 \quad 1000$

Bending Moment (kNm) Bending Moment (kNm)
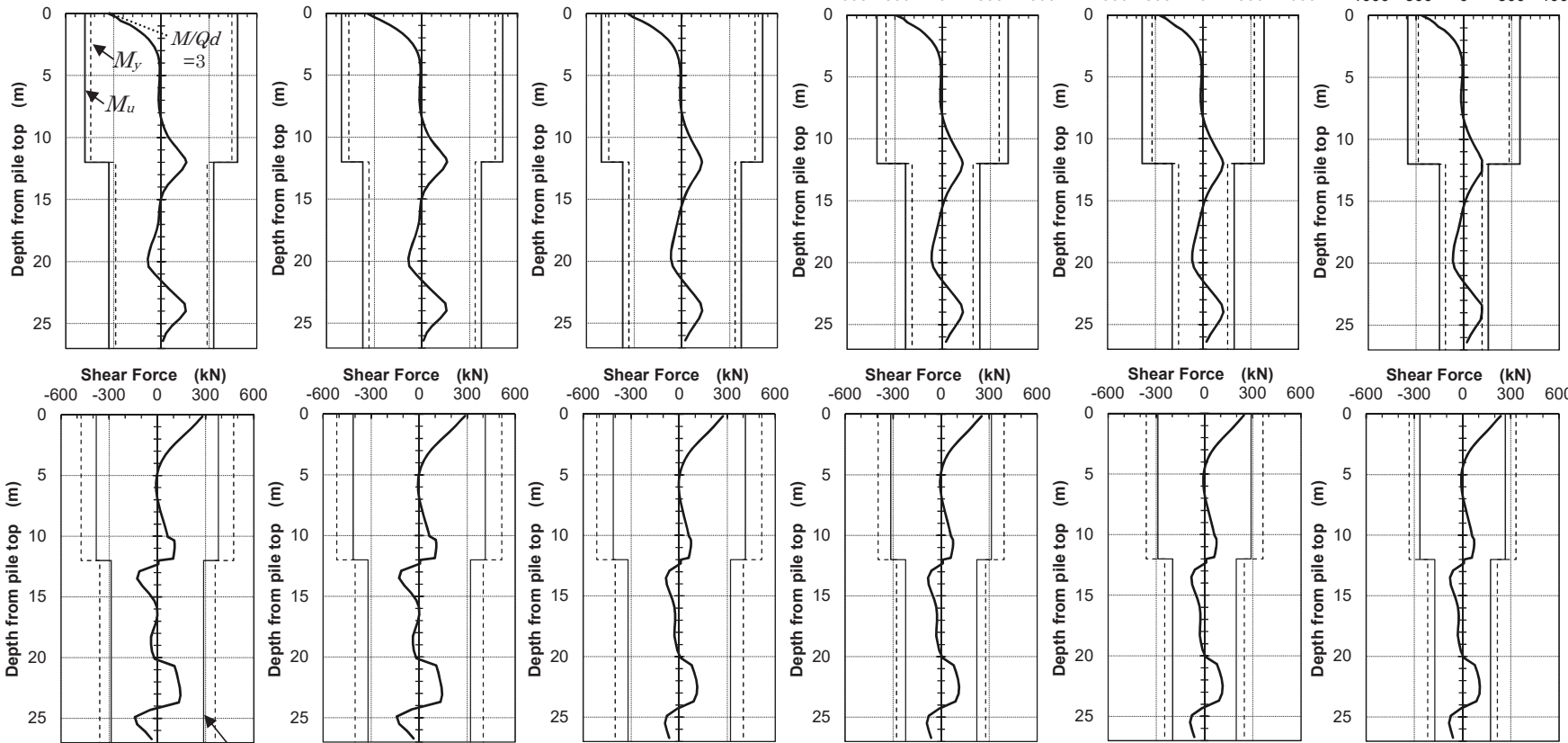

No.1 $Q_{u}$ considering

No.4

No.8/9/10

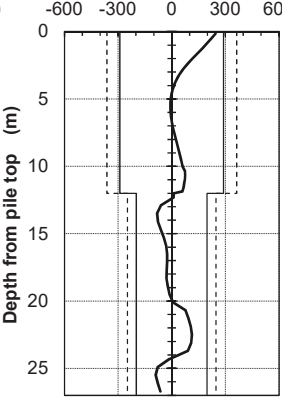

No.11/12

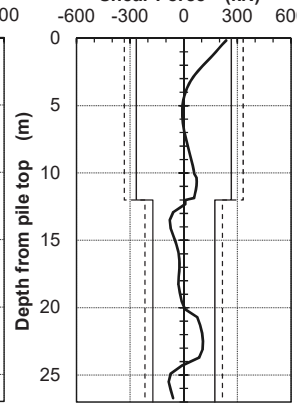

No.13/No.14

Fig.9 Bending moment and shear force of plies(Case1)

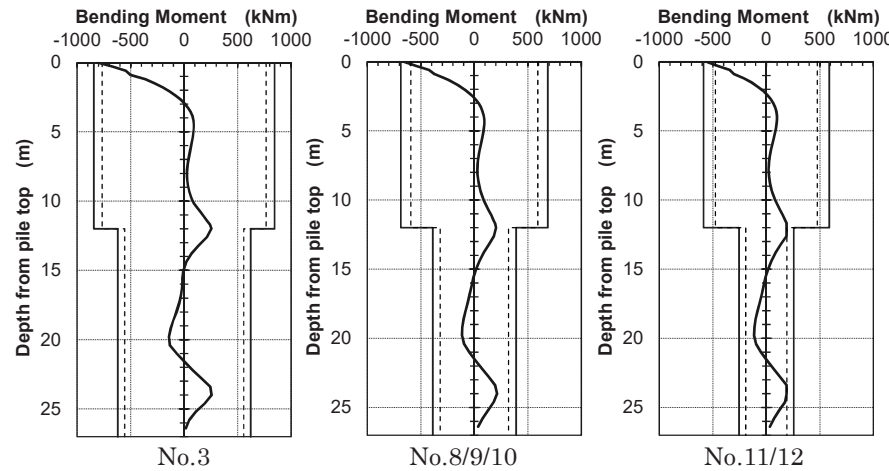

Fig.10 Bending moment of plies(Case2-1)
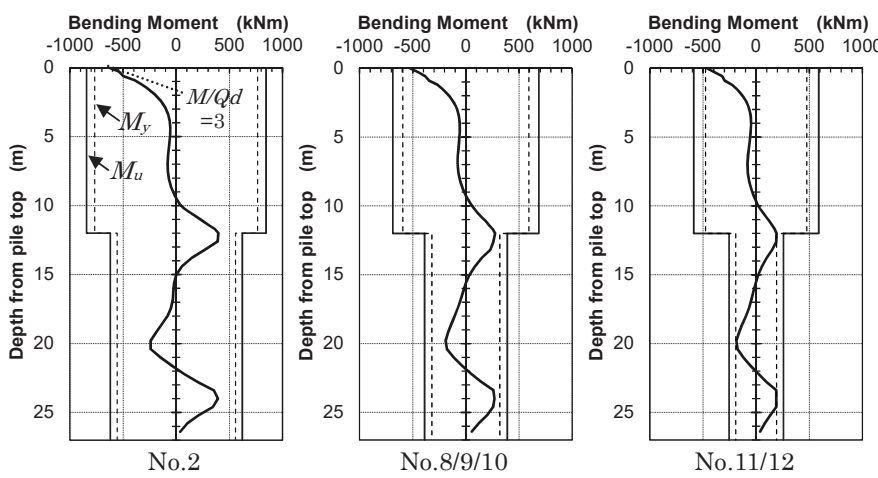

Fig.11 Bending moment of plies(Case2-2)

Fig.12 に地盤震動以外の地盤変位としてやや深い層の腐植土層 下端境界部から変位を加えた Case3-1A·B の結果のうち No.3・ No.8/9/10・No. 13/14 について示す。図中の○は終局曲げモーメント あるいはせん断耐力に達したことを示す。ここで変位量 $50 \mathrm{~mm}$ (Case 3-1A)では曲げモーメント・せん断力ともには終局状態には至ってい ないが，100mm(Case3-1B)になると杭頭は終局曲げモーメントに， No5 14 では杭頭から $6 \mathrm{~m}$ 付近ではせん断耐力に達した。本ケース の結果からは Table1に示した地中部で推定される損傷の原因とし

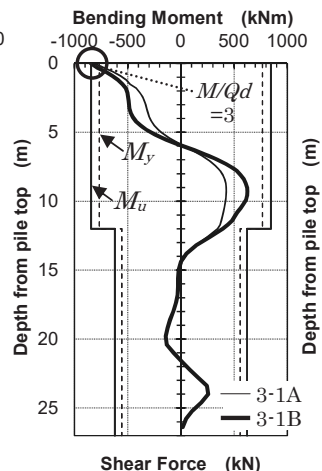

$\begin{array}{cc}\text { Shear Force } & (\mathbf{k N}) \\ -600-300 \quad 0 & 300\end{array}$

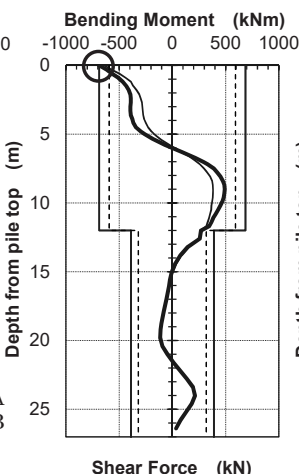

Shear Force $(\mathbf{k N})$

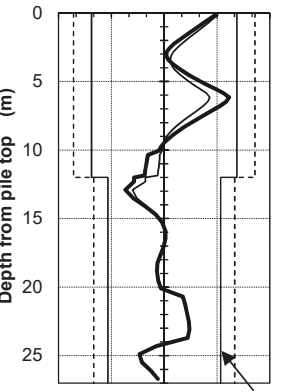

No.2 $Q_{u}$ considering

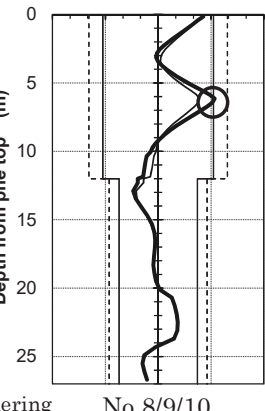

No.8/9/10

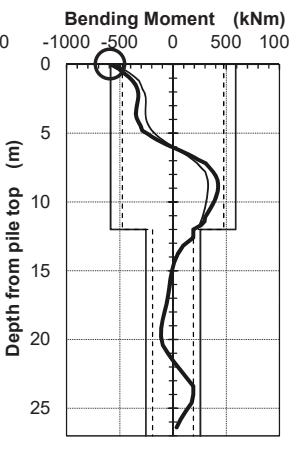

Shear Force $(\mathbf{k N})$ $\begin{array}{ccccc}-600 & -300 & 0 & 300 & 600\end{array}$

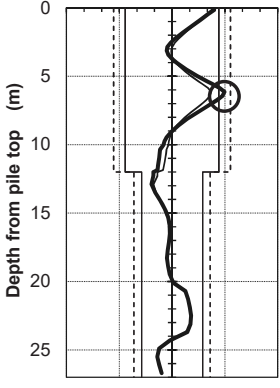

No.11/12

Fig.12 Bending moment and shear force of plies(Case3-1A $3-1 \mathrm{~B})$

ては, 腐植土層付近の軟弱層で地盤変位が生じたことが考えられる。

Fig.13 地表面付近の盛土層での地盤変形を加えた Case3-2 の結 果のうち，北側の No.1·No.11/12，南側の No.3・No.4・No.8/9/10 • No.13/14 の曲げモーメント分布およびせん断力分布を, Table6 に 各杭が $M_{u}$ あるいは $Q_{u}$ に達したときのステップ数を示す。ここで, いずれの杭も 30 ステップまでにほぼ終局耐力かそれに近い值に達 しているが, 軸力が最大で後方杭の No.4 やそれより軸力は小さい が地盤変位が大きい前方杭の No.2 では $Q_{u}$ に達する以前に $M_{u}$ に達 している（2 節の破壞パターン(2)）。それに対し，地盤変位が大きく 

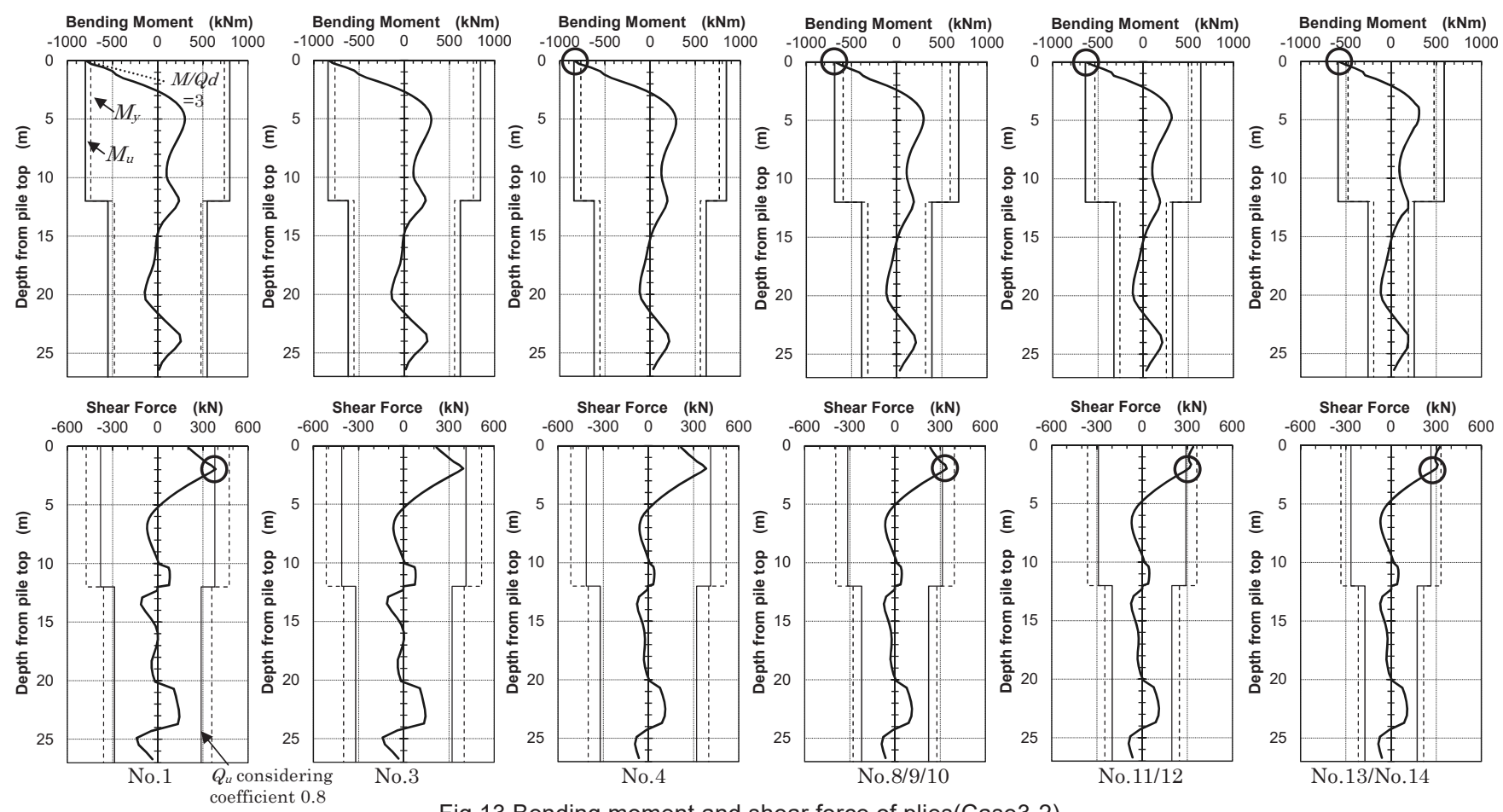

Fig.13 Bending moment and shear force of plies(Case3-2)

Table6 Load step at reaching $M_{u}$ or $Q_{u}$

\begin{tabular}{cccccccc}
\hline & No.1 & No.2 & No.3 & No.4 & No.5 10 & No.11/12 & No.13/14 \\
\hline$M u$ & - & 30 & - & 30 & 28 & 25 & 26 \\
$Q u$ & 30 & - & - & - & 26 & 25 & 24 \\
\hline
\end{tabular}

軸力が小さい前方杭のNo.1では $Q_{u}$ に先に達しており（破壊パター ン(1)), これらの結果は Fig.4 に示寸被害状況と概ね対応する。さら に軸力が小さい No.5 14 では $M_{u}$ と $Q_{u}$ にほぼ同時に達しており, 軸力や地盤変位の差による破壊パターンの違いが確認された。

一方, No.2（破壊パターン(4)）やNo.13/14（3) についても同様 に地盤震動以外の地盤変位が主要因と推測されるものの, ここで設 定した解析条件のみでは他の杭と異なる挙動を示す結果は得られな かった。実際の建物では, 同じパイルキャップ内でも軸力や地盤変 位の違いがあったことも考えられるが，現状の知見からはこれらを 定量的に設定することは困難であり, 被害データの蓄積や構造実 験・解析による今後の検証が必要である。

以上，Case3-2 では 1 本ずつ異なる被害す心゙ては説明できていな いものの，杭頭付近の破壊状沉の傾向としては対応寸る結果が得ら れており, 地表に近い部分で地盤震動とは別の変位が加わったこと が本建物での杭の破壊とそれに伴う傾斜の発生の主要因ではないか と推定される。このことは, 隣接する地下階のある既存建物で, 杭 の調査はされていないが, 傾斜等の被害は見られなかったこととも 対応していると考えられる。

Fig.14 に設計水平震度 $k=0.6$ として地盤変位を考慮していない Case 4 の結果を示す。応力解析方法は異なるが，この荷重は原設計 に相当するもので, 曲げモーメントについては発生応力と終局耐力 がほぼ対応する。それに対し, せん断力は本論文で採用したせん断 耐力を超えており, 設計時の目標性能はこれとは異なっていたと思 われる。これらの結果をC Case1 の結果（Fig.9）と比較すると, 大 地震時の設計外力として地盤変位を考慮せず設計用水平震度を大き くする設計方法は安全側の設定となっているが，地盤震動以外の地
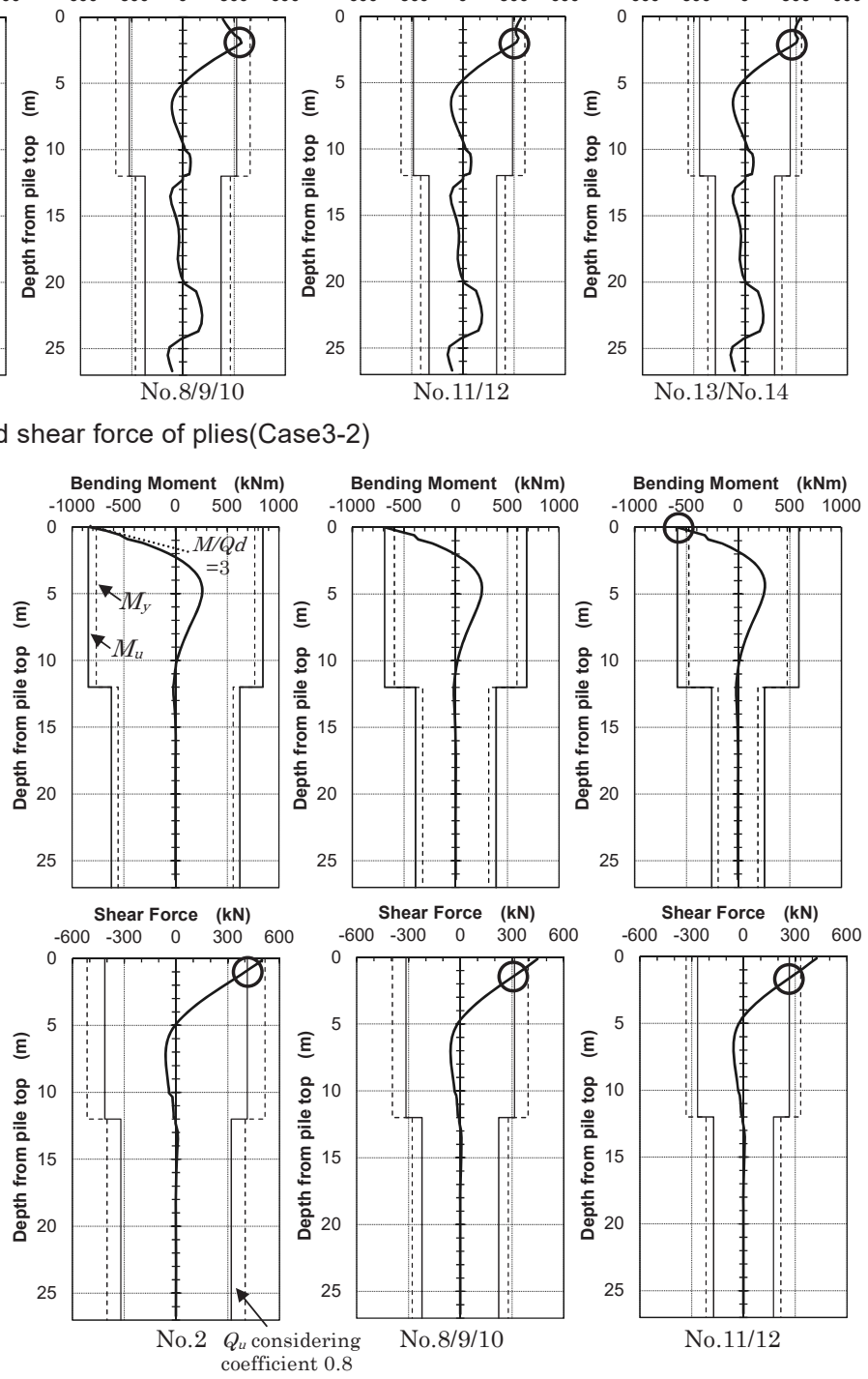
杭頭の被害発生への影響が支配的と考えられる浅い層のばね值は既 往の設計式 10) と概ね対応寸る設定であるが，深い層の評価についは 実測データ等に基づく検証が必要と考えられる。

本建物の杭は大地震時の耐震性を考虑して設計されており, 地盤 震動による地盤変位を含む大地震時の地震動に対しても杭の耐震安 全性は確保されていたと考えられるが, 地中もしくは地表に近い層 で想定を超える地盤変形が加わったために被害に至った可能性が考 えられる。ここから, 活断層に近い場所などでは護岸付近の地盤の 液状化による側方流動と同様に, 地盤震動以外の地盤変位が加わっ て杭の耐震性に影響する可能性があり, そのような地盤変位を考慮 して安全余裕を確保するなどの設計上の配慮が必要であることが示 唆される。

\section{6. 結論}

2016 年熊本地震で被害を受けた杭について被害状況を整理し, そ の被害要因分析のためのシミュレーション解析を実施した。得られ た結論を以下に示す。

1） 2016 年熊本地震でも, 上部構造の被害はほとんどないにもかか わらず杭が損傷して傾斜し継続使用不能となった建物が見られた。 杭種は既製コンクリート杭, 地盤は沖積低地, 被害パターンの混 在など, 被害の特徴は 2011 年東北地方太平洋沖地震と共通する。

2）本研究で用いた非線形性を考慮してモデル化した杭材と地盤ば ねからなるはり-ばねモデルに, 観測された地震動に基づいて導い た杭頭水平力および地盤震動以外の変位を含む地盤変位を荷重・ 外力として与えた解析手法により, 大地震時に杭が被害に至る挙 動の評価が可能であることを確認した。

大地震時の杭の構造性能を確保し建物の継続使用をはかるため には，断層近傍など地盤震動以外の地盤変位の影響が想定される 場合においては, 低層建物や液状化の可能性が低い地盤であって も地盤変位に対する配慮が望ましい。

3）解析結果は全体の被害傾向と概水対応しており, 各杭の被害の違 いは群杭効果の影響は少なく, 軸力や地盤変位分布の影響の可能 性が考えられる。杭 1 本ずつの被害状況の違いや 1 ケ所のみ地中 部で逆方向に破損していることの説明のためには, 同一フーチン グでもそれぞれ別の解析条件を設定しなければならないと思われ るが，今後の被害データの蓄積や実験・解析に基づく定量的評価 方法の構築が必要である。

4）設計水平震度として 0.6 のような大きな值を用いて地盤変形を 考慮しない設計方法は, 大地震時の設計手法として安全側の設定 となっていると考えられるが, 地盤震動以外の地盤変位が想定さ れる場合には, せん断耐力の安全余裕の確保など安全性に対する 十分な配慮を行うことが望ましい。

5）本論文では, 被害シミュレーションを通じて地盤震動以外の地盤 変形が杭基礎の耐震性に影響を及ぼす可能性を示した。ただし本 解析では, 工学的基盤の地震動を約 $3 \mathrm{~km}$ 離れた観測点と同じと したことや地盤変位の設定方法, 入力損失, 前震の影響の定量的 評価など被害状況を考慮した上での仮定に基づく条件設定も多い。 また，地盤ばねや杭体・杭頭接合部の実測や実験データに基づく モデルの高精度化などとあわせ, 耐震性評価法としての一般化の ためには今後のデータの蓄積と検証が必要である。

\section{謝辞}

本研究にあたっては, 益城町, 日本下水道事業団および工事関係 者の皆様より資料提供他のご協力をいただきました。記して深謝し ます。また, 解析のための地震波は防災科学技術研究所基盤強震観 測網(KIK-net)の記録を利用しました。

\section{参考文献}

1) Quick report of the field survey and the building damage by the 2016 Kumamoto earthquake, TECHNICAL NOTE National Institute for Land and Infrastructure Management No.929/Building Research Data No.173, pp.5.5.43-46, 2016.9 (in Japanese)

平成 28 年熊本地震建築物被害調查報告（速報），国土技術政策総合研究所 資料第 929 号／建築研究資料第 173 号, pp.5.5.43-46, 2016.9

2) Kaneko O. et al.: Situations and analysis of damage to pile foundations of buildings in 2011 Great east Japan earthquake, the JGS journal, vol.62, No.1, pp.16-19, 2012.1 (in Japanese)

金子治ほか 5 名 : 2011 年東日本大震災における建築物の杭基礎の被害状況 と要因分析, 地盤工学会誌, vol.62, No.1, pp.16-19，2012.1

3) Kaneko O. and Nakai S.: Evaluation of seismic performance of pile foundations damaged during the 2011 Great east Japan earthquake, Journal of Structural and Construction Engineering (Transactions of AIJ), Vol.79 No.695, pp.83-91, 2014.11 (in Japanese)

金子治, 中井正一, 東日本大震災において被害を受けた杭基礎の耐震性の 評価, 日本建築学会構造系論文集, 第 79 巻, 第 695 号, pp.83-91, 2014.1

4) Kaneko O. et al.: Analytical study on damage factor of pile foundations during the 2011 Off the Pacific coast of Tohoku earthquake, Journal of Structural and Construction Engineering (Transactions of AIJ), Vol.80 No.717, pp.1699-1706, 2015.11 (in Japanese) 金子治ほか 4 名, 東北地方太平洋沖地震における杭基礎の被害要因に関寸る解 析的検討, 日本建築学会構造系論文集, 第 80 巻, 第 717 号, pp.1699-1707, 2015.11

5) Futaki M., Kaminosono T. and Nakata T.: Damage grade classification manual of building foundations and some examples of repair techniques, Kenchiku Kenkyu Shiryo, No.90, pp.11-34, 1997.8 (in Japanese) 二木幹夫，上野薗隆志，中田慎介編，建築基礎の被荻度区分判定指針及び 復旧技術例，建築研究資料，No.90，pp.11-34，1997.8

6) Ohta, H. and Goto, I.: S-Wave Velocity in Terms of Characteristics Indices of Soil, BUTSURI-TANKO (Geophysical Exploration), Vol.29, No.4, pp.31-41, 1976.8 (in Japanese)

太田裕, 後藤典俊 : $\mathrm{S}$ 波速度を他の土質的諸指標から推定寸る試夕, 物理 探鉱，第 29 巻，第 4 号，pp.31-41, 1976.8

7) Yasuda, S. and Yamaguchi, I.: Dynamic soil properties of undisturbed samples, 20th Japan National Conference on Soil Mechanics and Foundation Engineering, pp.539-542, 1985 (in Japanese)

安田進, 山口勇, 種々の不䚓乱土における動的変形特性, 第 20 回土質工学 研究発表会概要集, pp.539-542, 1985

8) Sugimura, Y. and Hirade T.: Experimental study on degree of restraint for rotation and failure strength of prestressed high strength concrete pile-footing joint, Journal of Structural and Construction Engineering (Transactions of AIJ), No.373, pp.111-120, 1987.3 (in Japanese)

杉村義広, 平出務, 高強度プレストレストコンクリート杭とフーチング接 合部の回転拘束度および破壞耐力に関する実験的研究, 日本建築学会構造 系論文報告集，第 373 号，pp.111-120，1987.3

9) Mase T. and Nakai, S,: Examination of soil spring setting method of single pile, Journal of Structural and Construction Engineering (Transactions of AIJ), No.680, pp.1527-1535, 2012.10(in Japanese) 間瀬辰也, 中井正一: 単杭の杭周地盤ばねの評価法に関する検討, 日本建 築学会構造系論文集, 第 77 巻, 第 680 号, pp.1527-1535, 2012.10

10) Recommendations for design of building foundations, AIJ, pp.268-284, 2001.10(in Japanese)

建築基礎構造設計指針，日本建築学会，pp.268-284，2001.10

11) Kishida S. et al.: The calculation method for the ultimate shear strength of large diameter PHC piles, Journal of Structural and Construction Engineering (Transactions of AIJ), No.532, pp.103-110, 2000.6(in Japanese) 岸田慎司ほか 3 名 : 大口径 PHC 杭のせん断終局強度の計算方法に関寸る 研究, 日本建築学会構造系論文集, 第 532 号, pp.103-110, 2000.6 


\section{ANALYSES OF DAMAGE TO PILE FOUNDATIONS BY \\ THE 2016 KUMAMOTO EARTHQUAKE}

\section{Osamu KANEKO* and Nobuhide NARITA**}

* Research and Development Center, Toda Corporation, Dr. Eng.

** Research and Development Center, Toda Corporation, M. Eng.

The authors investigated the damage of pile foundations during the 2016 Kumamoto earthquake and carried out simulation analyses to estimate a cause of the damage. We show below conclusions provided by these studies.

It occurred that a building was inclined and became unusable continuously for the damage of pile foundations, though there was little damage of the superstructure by the earthquake. The damaged building had the following characteristics, those were that the kind of piles was pre-stressed concrete piles, and the building was built on the alluvial plain, and there were various damage patterns of piles. These events were common with the 2011 off the Pacific coast of Tohoku earthquake.

To analyze process reached to severe damage, a static analysis model consisted of both piles and ground springs considering nonlinearity was employed, and the lateral load calculated based on observed earthquake motion at pile head and ground displacement were given to this model. The results of our analyses showed that this analytical model was useful for evaluation of process reached to damage and estimation of seismic performance of pile foundations during severe earthquakes.

It was confirmed that the damage did not occur when only load caused by earthquake motion was given to piles, in contrast the results obtained by our analyses almost accords with the actual damage situation when ground displacement by the cause except the earthquake motion was added. Influence of movement of the fault or embankment was thought about as for the prime cause of added ground displacement, but it is necessary to investigate quantitatively in the future.

To secure the performance of piles and continuous use after severe earthquake of the building on particular ground condition like nearby the faults, the consideration for the ground displacement caused except the earthquake motion may be necessary even if it is relatively small building and is not the liquefaction ground.

Results obtained our analyses accorded mostly with tendencies of real damage, and this study showed that axial load and the ground displacement distribution have a strong influence on the damage of each pile. On the other hand slightly difference of each pile in damage situation appeared. In order to explain the difference, analysis conditions must be set individually even if existing in the same pile cap. Therefore for realization of the quantitative method, accumulation of data about actual damage, structural experiments or analyses are necessary.

Judging from obtained results, when seismic designed method based on the condition that design horizontal seismic intensity was decided to 0.6 without ground displacement was employed, it seems assumption on the safe side against severe earthquakes. However, the design using this method may not guarantee safety when ground displacement by the cause except the earthquake motion occur, in particular a close investigation for securing of shear capacity is required. 